\title{
THE BEAUTY OF JINAS IN THE BOOK OF MIRQAT AL-MAHABBAH
}

\author{
Edi Komarudin \\ UIN Sunan Gunung Djati Bandung \\ Jl. A.H. Nasution 105 Cibiru Kota Bandung \\ Email: abugiyas@yahoo.co.id; \\ Deuis Sugaryamah \\ UIN Sunan Gunung Djati Bandung \\ Jl. A.H. Nasution 105 Cibiru Kota Bandung \\ Email: deuissugaryamah@uinsgd.ac.id
}

\begin{abstract}
$\underline{\text { Abstract }}$
Mirqat al-Mahabbah is a monumental work of a great scholar, KH. Aon Abdul Majid who was well-known as Ajengan Aon from Singaparna - Tasikmalaya and lived during the Indonesian independence struggle (1890-1934). This book is presented in Arabic language, laden with the beauty of the sentences. Using Ilmu Badi', the beauty of a sentence can be derived either from the "words" which is called al-Muhassinat al-Lafzhiyyah, and/ or the beauty that derived from the "meaning" known as al-Muhassinat al-Maknawiyah. Among the types of beauty referencing the words are jinas, iqtibas and saja'. This study focuses on discussing the beauty of the phrases/ sentences in Mirqat al-Mahabbah only from jinas. The results indicate the varieties of jinas diverse in the book, thus symbolizing the aesthetic of such literary work.
\end{abstract} Keywords: Mirqat al-Mahabbah, al-Muhassinat al-Lafzhiyyah, jinas.

\section{A. Introduction}

Language is one aspect that cannot be separated from the life of mankind. Language always exists and is represented by human in the nature, in the history and in the revelation of God (Asep, 2009: 21).

$$
\text { Balaghah, Nahwu, Sharaf, }
$$

Linguistics, Semantics, and others are few of grammars and fields of study commonly used and learnt in Arabic language. Balaghah in this case refers to an approach for exploring various Arabic texts as well as a thing that might guide a person to be intelligent language speakers in everyday life (Rane Wellek and Austin Warren, 1989: 2).
A person's intelligence barometer, one of which can be seen from the language he used. The choice of words, styles of language and the way he speak shows the extent of the person's intellectual ability and prowess. In Arabic terms, such person is included in the category of mutakallim fashih, i.e. a person who speaks in precise, clear and good manners. The Arabians call this language proficiency level with the term balaghah (Yuyun, 2007: 1). Balaghah is as a discipline that is based on the clarity of the soul and accuracy in capturing the beauty and clarity of the vague difference between the various uslub (expressions). (Ali AlJarim and Mustafa Amin, 2013: 6). 
As an approach, in addition to be an "instruments of analysis" to explore Arabic religious texts, such as Al-Qur'an, hadith or Arabic literary texts, Balaghah may guide people as well to be intelligent language speakers in daily life (Yuyun, 2007: 2) .

Titian Cinta (Mirqat al-Mahabbah) is the work of Raden Haji Abdul Majid which contains the praises to the Prophet Muhammad with language full of beauty. Such beautiful expressions can be seen from the use of many jinas, which is a form of beauty as the references to the word, using Ilmu Badi' as part of Ilmu Balaghah.

Some considerations to do the research focusing on jinas in the book of Mirqatul Muhabbah are: first, this book is always read by some Muslims in every Maulid (Muludan = commemorating the birth of Prophet Muhammad SAW) and in some Islamic teachings (qur'anic recitation or pengajian-pengajian). Second, an attempt to keep the legacy of the past scholars and preserve the values contained in it, considering the book is used as guidelines for Muslims, especially in Tasikmalaya, West Java. Third, this book can increase the level of faith of those who believe as a form of worship. Fourth, the editorial style of jinas used in the book, not without purpose, is considered as the addition to strengthening the language aesthetics as well as conveying moral messages.

Using the theories of Ilmu Badi' to explore the type of jinas in the book of Marqotul Muhabbah by Raden Haji Abdul Majid, this research is expected to participate in overcoming the shortage of literature about the beauty of the words in Arabic, as well as a reference to the development of similar further research.

The primary data source is the book Mirqat al-Mahabbah and the secondary data are dictionaries (al-ma'äjim) and some books that are relevant to this study.

\section{B. Literature Review}

Ilmu Badi 'is a knowledge or technique that discusses the way to beautify a phrase, either on the aspects of lafadz or on the aspects of meaning. There are two important sections discussed in Ilmu Badi': al-muhassinat al-lafzhiyyah and almuhassinat al-ma'nawiyyah (Abdul Aziz Atiq, 2009: 76).

There are sixteen parts of almuhassinat al-lafdziyyah expressed by alHashimi: Jinas, Tashiif, Izdiwaz, Saja ', Muzawanah., Tarshi', Tasyri ', Luzuum ma la yalzimu, Roddul azzi a'la al-shadri, Ma la yastahiilu bil in'ikas, Almuwarobah, I'tilafu al-lafdzi ma'a al-lafdzi, Tamsiith, Insijam wa temperatur, Iktifa ', and Tathriiz. (Al-Hasyimi (1960: 361)

Then there are thirty-six parts of $a l$ muhassinat al-ma'nawiyah: attauriyah, istikhdam, istithrod, iftitan, thibaq, muqobalah, maro'atun nadzir, irshad, imdimaj, madzhab kalami, husnu ta'lil, tajrid, musyakalah, muzawarah, athoyu wanasru, aljam'u, tafriq, taqsim, jam'u wa tafriq, mubalagah, mughayaroh, ta'kidul madhi bima yusbihu dzam, takidu ad-dzam bima yusybihu madhu, taujih, nafyu sai bi ijabihi, qoulu bil maujib, i'tilafu lafdzi ma'al meaning, tafri'i, istitba ', as-salbu bil ijab, uslubul judge, tasyabuhuh athraf, al-'aksu, and tajahul a'rif. Yet, this paper focus on discussing jinas as one form of language style which is Al-Muhassinat Al-Lafzhiyyah.

According to Basyuni (2011: 271) jinas, tajnis, mujanasah, and tajanus is derived from the word jinsi. According balaghah experts, jinas are two similar words but have different meanings. Ali alJarimi (2007: 283) argues that jinas is 
divided into two parts: (1) Jinas Tam: similarity in two lafadz in four aspects, namely the aspects of huruf, harakat, number of letters, and arrangement letters. (2) Jinas Ghair tam: similarity in two lafadz, yet different in one aspect of the above four aspects.

According to Dr. Abdul Aziz Atiq (2007: 197) jinas tam is divided into three parts namely tam mumatsil, Jinas tam mustaufi and Jinas tarkib. Jinas tam mumatsil are two same lafadz having similarity in the forms, both fi'il (verb), both isim (noun), or both letters. Jinas tam mustaufi are the same two lafadz, but have differences in the forms, one of the two lafadz is in the form of $f i^{\prime} i l$, and the other is in the form of isim or vice versa. The Jinas Tarkib are two similar lafazh but one of its lafazh is a combination of two words, such as in a poem:

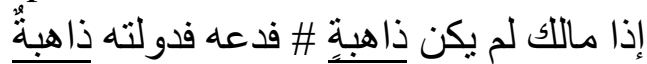

Meaning: "When he has something, he does not like giving. So leave him, his power will be lost".

The origin of lafadz ذبة ذا iهبة is , ذاهبة , its form is isim five. While the second lafadz ذاهبة is originated from ذاهبة the form is one lafazh.

Al-Hashim (1960: 296) argues that jinas is divided into two parts namely jinas lafdzi and ma'nawi. Jinas lafdzi is divided into eight parts, namely:

\section{Jinas tam}

Jinas Tam refers to the similarity of two lafadz in four aspects, namely the form of letters, the number of letters, vowel letters, and the arrangement of letters, then both the lafadz has its different meaning. Jinas tam is divided into two parts namely tam mumatsil and mustaufi. Then the types of jinas tam are the form of fi'il (verb), isim (noun), and hurup (letters).
Jinas tam mumatsil is the same two lafadz and has the equivalent in shape, $f i^{\prime} i l$ (verb), isim (noun), and huruf (letters).

Jinas tam mustaufi is the same two lafadz, but differ in the shape, one of the two lafadz was $f i$ ' $i l$, and another one is in the form of isim, or vice versa.

Jinas ghair tam are two similar lapadz, but different from one or more of the four aspects, namely the shape of the letter, the number of letters, vowel letters, and character sets. It can then differ in terms of the number of letters, in which not more than one letter at the beginning, middle, or end.

a. The difference of one letter located at the beginning of lafadz is called marduf. Example:

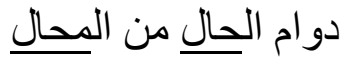

b. The difference of a letter located in the middle of lafadz, called muktanif. Example:

$$
\text { جذّى جهدى }
$$

c. The difference of one letter lying at the end of lafadz, called mathruf. Example:

\section{Jinas muthlaq and jinas isytiqo.}

$$
\text { الهوى مطية الهو ان }
$$

This refers to the similarity of two lafadz in two aspects, namely huruf (the letters) and susunan huruf (the character sets), both are not derivations (isytiqoq). If both are derivations, it is called jinas isytiqoq. Example:

$$
\text { لأعبد ماتعبدون و لا أنتم عابدون ماأعبد }
$$

The underlined three words constitute a single unit or a derivation of the verb عبد أعبد يعبد is fi'il mudhari with its fa'il dhamir mutakallim ana, while تعبدون is fi'il mudhari with its fai'l dhamir mukhataba antum, and عابدون is the form of fai'l isim with dhamir antum.

\section{Jinas mudzayyal and jinas mutharaf}

Jinas mudzayyal is a jinas that has an additional two letters in the end, as in the poem of Abu Tamam: 
يمدون من أيد عو اص عو اصح \# تصول بأسياف قو اضب قو اضب من اضب

قو اضب قو اض فو اض مو اصم عو اص The word is a kind of mudzayyal jinas because both have extra letters, letters mim on عو اصم word after عو اص word, and letter $b a$ on قو اض word after قو اضب

Jinas mutharaf are jinas that have extra letters at the beginning, as in the poetry of Sheikh Abdul Qohir:

$$
\begin{aligned}
& \text { وكم سبقت منه الى عو ارف \# ثنائى على تلك ف }
\end{aligned}
$$

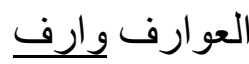

$$
\begin{aligned}
& \text { وكم غرر من برهولطائف \# لنكري على تلك } \\
& \text { اللطائف طائف }
\end{aligned}
$$

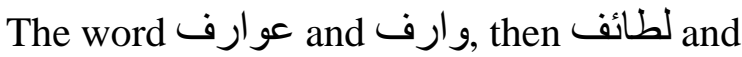
طائف is a type of jinas mutharaf because there is an extra huruf at first. Ain in the word عوارف, and lam on the word طائف.

\section{Jinas mudhari' and lahiq}

Jinas mudhari' is jinas that have differences from two types of letters with ليل adjacent makhroj. As in the sentence

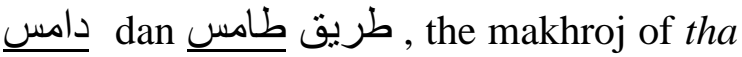
and dal on دامس are adjacent, i.ei located on the tip of the tongue.

Whereas jinas lahiq are jinas that have differences from the two types of beginning letters with different makhroj, as in همزة and

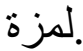

\section{Jinas lafdzi}

Jinas lafdzi is a jinas that has similarities in speech (utterance), but is different in writing, such as a poem:

$$
\text { الغز ال نظرة ولفتة \# من ذار آه مقبلا و لا افتنن }
$$

The two underlined words have similarities in terms of pronunciation but different in writing, which is different between nun and tanwin.

The difference of writing in this lafdzi between nun with tanwin, dlo (الضاض) with zha (الظاء), hurup ha (الهاء) with ta (التاء). like in the following example:

ولقد ظنتت بك الظنو \# ن لأنه من ضنّ ظنّ 6. Jinas muharraf and jinas mushohaf

Jinas muharraf is a different kind of jinas, for example: جُبَّةُ الَبْرْدِ (sutured tunic) and جُبُّةُ البَرْنِ (protector of the cold). Whereas jinas mushohaf are jinas having the same jurisdictions, but their points are different. Example as in the sentence:

$$
\text { إذا زلّ العالم زِلِ بزَلّْه العالم }
$$

\section{Jinas murokab and jinas mulaffaq}

Jinas murokab is the jinas having similar writing, i.e. the poem:

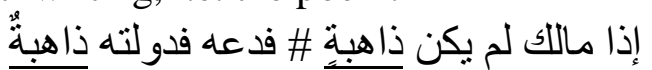

Meaning: "When he has something, he does not like giving. So leave him, his power will be lost."

The first Lafadz ذاهبة is derived from ذاهبة sive $i$, the form is five While the second lafadz ذاهبة ذاهبة is from its form is one sentence.

8. Jinas qolb, jinas qolb ba'di kul, and jinas maqlub mujannah

Jinas qolb is a jinas with different type of letters arrangement, for example:

$$
\text { حسامه فتح لأوليائه حتف لأعدائه }
$$

Meaning: "His sword is a help to his followers and the death of his enemy."

Jinas qolb is divided into two parts, jinas qolb ba'di kul and jinas maqlub mujannah. Qolb ba'di kul is a partial difference from the letters, i.e.

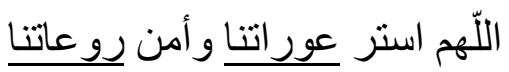

Jinas maqlub juli mujannah is the jinas in which there are two different lafadz arrangement of letters, at the beginning or at the end of the stanza, such as:

$$
\text { لاح أنوار الهدى \# من كفه في كل حال }
$$


Meaning: "the light of the clues has appeared from the palm of his hand at every step."

The second form of jinas according to Al-Hashimi is jinas ma'nawi, namely jinas idhmari and jinas isyaroh.

\section{Jinas idhmar}

Jinas idhmar is the jinas in which the purpose of its lafadz is different from the intention according to the context of the language, such as in the sentence:

منعم الجسم تحكى الماء رقته \# و قلبه قسوة يحكى أوس أجس

\section{Jinas isyaroh}

Jinas isyaroh is a jinas in which one of his lafadz is not mentioned, as the phrase:

Meaning: "Asad has run from the tiger"

$$
\text { فرّ الأَسدُ من إسمه }
$$

Isim dhamir on lafadz إسمدا return to lafadz with the meaning of tiger. Lafadz أسد with the meaning of the tiger is not mentioned, because there are already lafadz أسد which is used as the name of the person.

\section{Discussion}

\section{Jinas in the Book of Mirqat al-Mahabbah}

Presented below are some data samples showing some forms of jinas in the book Mirqotul Mahabbah. The followings are the cause of Jinas on the lafadz:

\section{Jinas Isytiqaq}

In the book of Mirqat al Mahabbah, jinas isytiqaq is found. This refers to the two lafazh which have similarities in huruf (letters) where both are formed from the root of the same word. Jinas isytiqaq can be seen in the underlined words of following sentences:

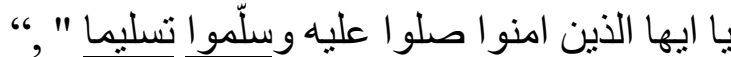

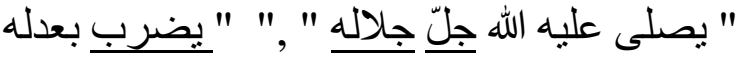

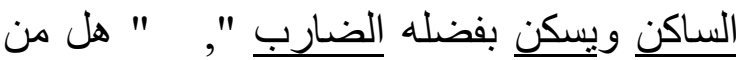

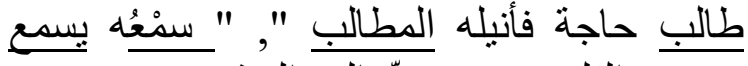
صرير القلم ", " وحنّ اليه الجذع حنين حزين نأدب ", " في موكب من الملائكة يفوق على سائر

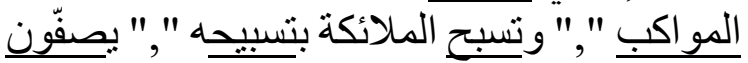
في الصلاة كصفوفهم في القتال "," وأطهّره و واهل

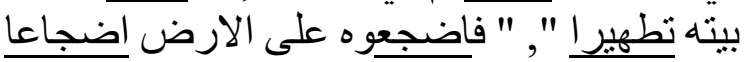

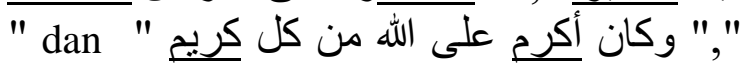

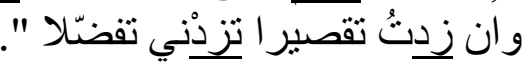

\section{Jinas Muthlaq}

Jinas muthlaq is lafadz which has similarities in letters along with their letters arragement, yet both are not derived from the same word. Jinas Muthlaq can be seen in the underlined words in the following sentences:

" لااله الاالله حكيم اظهر بديع حكمه و العجائب

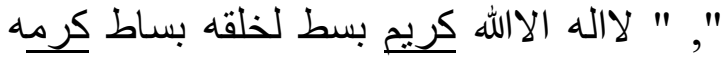

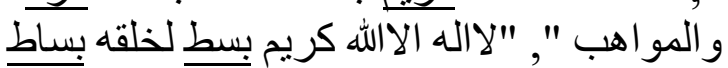

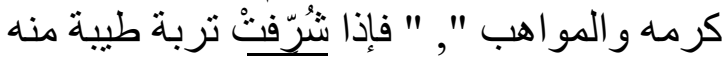
بأثرف كرده قالب ", " الأبي اوجدته قبل وجود

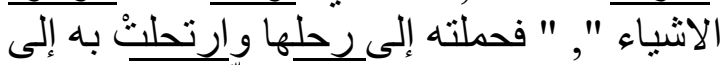

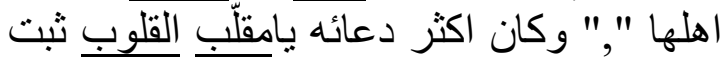
قلبي على دينك "," ويوجد منه أحسن طيب و وان لهن لم يكن قد تطيّب "," فذو العرش محمود و هذا

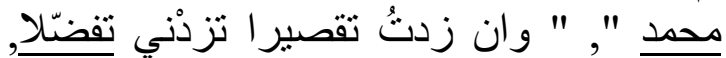

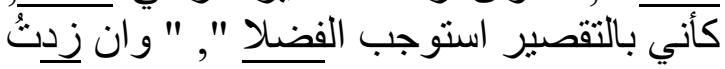

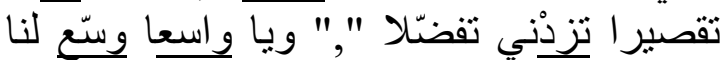

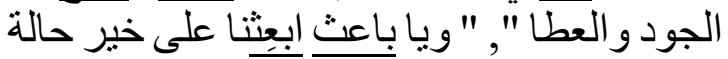

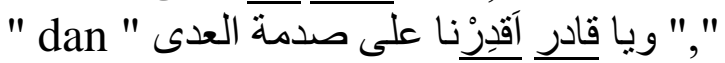

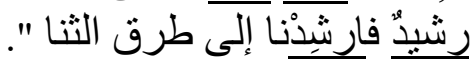

\section{Jinas Muharraf}

Jinas Muharraf is two lafazh that have differences in their font type (huruf/ letter/ typeface). Jinas Muharraf can be seen in the underlined words available in the following sentences:

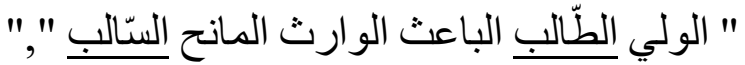

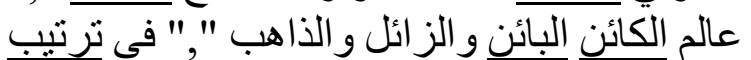
تركيب هذه القوالب "," " آمن به الضبن الضب وسلمت عليه الاشجار وخاطبته الاحجار ", " وحنّ اليه 
الجذع حنين حزين نأدب "," ثم ارده من العرش

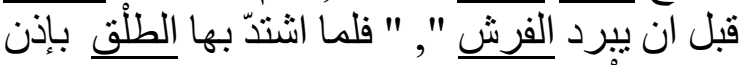

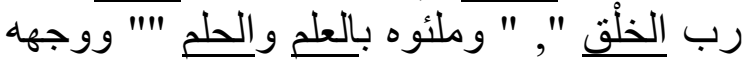
متهلل كنور الصباح اذ اقبلت حليمة معلنة بالصياح

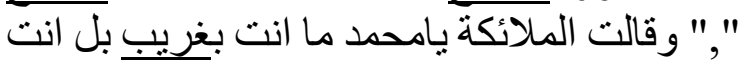

$$
\text { من الله قريب "وتب }
$$

\section{Jinas Tam Mumatsil}

Jinas mumatsil are two lafazh that have similarities in font type, syakalhuruf, number of letters and sequence of letters yet have different meanings. Jinas Tam Mumatsil can be seen in the underlined words in the following sentences:

" بأن نبيه محمد صلى الله عليه وسلم يكون رضيعا

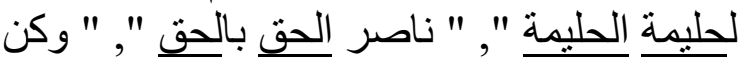

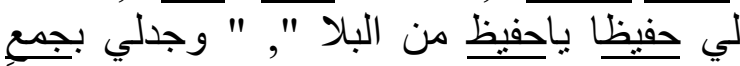

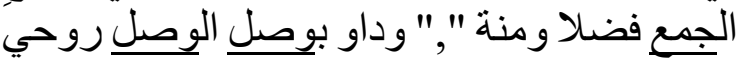

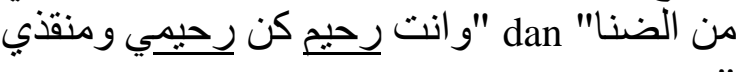

\section{Jinas Mushahhaf}

Jinas Mushahhaf are two lafadz that have similarities of the number of letters, but both have differences from nuqthah (dot). Jinas Mushahhaf is the words underlined streaked in the phrase "صد ياقهار وللضد للضد The jinas contained in the word and صد. The first letter of the word للضد is الضاد where there is a dot, and the first letter in the word الصاد is without dots.

\section{Jinas Mudhari}

Jinas Mudhari are two similar lafazh but have different letters. Jinas Mudhari is found in the words وسدد فثدد and وس on the sentence:

مقالتي وسدد ني فثدد منثن, the first letter of and the second letter of النين letters have a distant makhroj huruf.

\section{Conclusions and Recommendations Conclusion}

The findings show that the types of Jinas in the book entitled Mirqat al-Mahabbah include jinas isytiqaq, jinas muthlaq, jinas muharraf, jinas mumatsil, jinas mushahhaf and jinas mudhari'. The existence of such varieties of jinas shows that the language full of beauty is contented in the book of Mirqat al-Mahabbah.

\section{Suggestions}

Since this study focuses only discussing Jinas, it is suggested that other researchers may conduct further study on Mirqat alMahabbah with different approach to find different topic areas, such as comparing jinas with other lafazh beauty aspects, so that the findings shall enrich the references about Arabic language style.

\section{REFERENCES}

Abbas, Fadil Hasan, Dr, al-Balaghah Fununuha wa Afnanuha, Amman : Dar al-Nafais, 2008.

Ahdori,Abdurrahman. Juhar maknun. Semarang: Karya Putra, tt.

Ali Jarimi \& Musthafa Amin., al-Balagah al-Wadhihah. Jakarta: Raudhah Press, 2007

Atiq, Abdul Aziz, Dr, tt, Ilmu al-Badi', Beirut : Dar al-Nahdhah al'Arabiyah, 2009.

Dhaif, Syauqi.. Tarikh al-adab al-Arabi: alAshru al-Jahili. Kairo: Dar alMa'arif, tt

Fuyudi, Basyuni Abdul Fattah, Dr, Ilmu alBadi', Kairo : Muassasah al Mukhtar, 2011

Gufran, Muhammad.. Albalaghah fi ilmi badi'. Gontor : Darussalam, tt.

Hasyimi, Ahmad..Jawahirul Balagah. Beirut: al-Maktabah al-'Ashriyyah, 1999

Jadwa, Izzah Muhammad, Dr. Al-Balaghah al-'Arabiyah, Riyadh : Maktabah alRusyd, 2014. 
Kamil, Sukron. Teori Kritik Sastra Arab: Klasik dan Modern. Jakarta: UIN Jakarta Press. 2008.

Munawwir.. Kamus Al-Munawwir ArabIndonesia Terlengkap. Surabaya:Pustaka Progressif, 1997

Qodur, Muhammad. Mabadi lisaaniyyat. Suriah: Darul Fikri. 1996

Ratna, Nyoman Kutha. Teori, Metode, dan Teknik Penelitian Sastra, Yogyakarta: Pustaka Pelajar, 2004.

Sumardjo, Jakob dan Saini K.M, .Apresiasi Kesusastraan. Jakarta: Gramedia, 1988

Wahab Muhsin \& Fuad Wahab. PokokPokok Ilmu Balagah. Bandung: Angkasa, 1986

Wahyuddin, Yuyun. Menguasai Balaghah: Cara Cerdas Berbahasa. Yogyakarta: Nurma Media Idea. 2007.

Warren, Austin dan Rane Wellek. Teori Kesusastraan. Jakarta: PT Gramedia. 1989 